\title{
TÜRKIYYE EKONOMISINDE İÇ VE DIŞ DENGE SORUNUNUN ÇÖZÜMÜNE YÖNELİK KAPSAMLI BİR ANALİZ
}

\section{A COMPREHENSIVE ANALYSIS REGARDING THE SOLUTION OF INTERNAL AND EXTERNAL BALANCE PROBLEM OF TURKEY'S ECONOMY}

\author{
Seher BAŞ ${ }^{1}$ \\ Burak SERTKAYA ${ }^{2}$
}

\section{$\ddot{O} z$}

Ekonominin temel amaçlarından biri iç ve dış dengenin sağlanmasıdır. Genellikle, ekonomilerde bu dengelerden en az birinde açık oluşmaktadır. Gelişmekte olan ülkeler açısından iç ve dış dengede görülen istikrarsızlıklar makroekonomik kırılganlıkların temel nedenlerinden biridir. Türkiye ekonomisinde son dönemde hem cari açık hem bütçe açı̆̆ı hem de tasarruf-yatırım açı̆̆ı birlikte görülmektedir. Bu noktada üçüz açı̆̆ın ne zaman endişe verici olduğu sorusu önem kazanmaktadır. Bu durum, söz konusu açıkların sürdürülebilirliğini gündeme getirmiştir. Üçüz açığın sürdürülebilirliğini analiz etmede, dış ticaretin yapısı, borçluluk düzeyi, mali disiplin, döviz kurlarl gibi iç ve dış denge üzerinde etkili olan birçok ekonomik faktör mevcuttur. Bu çalışmada, Türkiye'deki iç ve diş ekonomik dengeyi bozan unsurlar incelenmiş ve tasarruf-yatırım düzeyinin önemine yönelik kapsamll değerlendirmeler sunulmuştur. Buna göre, Türkiye’de iç ve diş ekonomik dengeyi bozan unsurlara yönelik politikaların geliştirilmesi daha kalıcı çözümler elde edilmesini sağlayacaktır.

Anahtar Kelimeler

Jel Kodlart
: Üçüz Açık Hipotezi, Tasarruf Yetersizliği, Enerji İthalatı, Sürdürülebilirlik

$$
\text { : E21, F32, H60, Q40 }
$$

\section{Abstract}

One of the main objectives of the economy is to provide the internal and external balance. Generally, a deficit occurs in at least one of these balances in economies. In terms of developing countries, instability in internal and external balance is one of the main causes of macroeconomic vulnerabilities. Recently in Turkey's economy, the budget deficit, current account deficit and saving-investment gap have been seen together. At this point, the question of when the triple deficit is alarming becomes important. This situation has brought the sustainability of these deficits to the agenda. In analyzing the sustainability of the triple deficit, there are many economic factors that affect the internal and external balance such as the structure of foreign trade, level of indebtedness, fiscal discipline, and exchange rates. In this study, internal and external economic balance distorting elements in Turkey were examined and comprehensive evaluation were presented for the importance of saving-investment

\footnotetext{
${ }^{1}$ Arş. Gör. Dr., Hitit Üniversitesi, İktisadi ve İdari Bilimler Fakültesi, Maliye Bölümü, seherbas@hitit.edu.tr, ORCID: 0000-0003-0974-6151.

${ }^{2}$ Dr. Öğr. Üyesi, Hitit Üniversitesi, İktisadi ve İdari Bilimler Fakültesi, İktisat Bölümü, buraksertkaya@ hitit.edu.tr, ORCID: 0000-0001-9551-3439.
} 
level. Accordingly, development of policies regarding the elements that distort the internal and external economic balance in Turkey will provide permanent solutions to the problem.

Key Words

Jel Classification
: Triple Deficit Hypothesis, Saving Deficiency, Energy Import, Sustainability

: E21, F32, H60, Q40

\section{GíRIŞ}

Ekonomilerin iç ve dış dengesinin sağlanmasında temel alınan göstergeler tasarruf-yatırım açığı, cari açık ve bütçe açıklarıdır. Basit bir ifadeyle cari açık; bir ülkede döviz giderlerinin döviz gelirlerinden fazla olmasını ifade ederken, bütçe açığı devletin giderlerinin gelirlerinden büyük olması durumunu ifade etmektedir. Tasarruf-yatırım açığı ise, yurt içi yatırımlarının yurtiçi tasarruflarla karşılanamaması durumudur. Söz konusu iç ve dış denge unsurlarının üçünün de aynı anda açık vermesi üçüz olarak adlandırılmaktadır. Makroekonomik dengenin sağlanması açısından istenmeyen bir durum olarak kabul edilen üçüz açık, hem gelişmiş hem de gelişmekte olan ülkeler için sorun teşkil edebilmektedir. Üçüz açık veren ülkeler için bir noktadan sonra açıkların sürdürülebilirliği daha çok önem kazanmaktadır. Bu bakımdan üçüz açık sorununun ortaya çıkardığı finansman zorluklarının yanında sürdürülebilirliği de tartışılmalıdır.

Türkiye son yıllarda ekonomide iç ve dış açıkla anılan ülkelerden biridir. Türkiye en başta cari açık vererek büyüyen bir ekonomidir. Türkiye'de cari denge ekonominin büyüdüğü zamanlarda genellikle açık vermektedir. Ekonominin küçüldüğü dönemlerde ise cari açık genellikle azalmaktadır. $\mathrm{Bu}$ durumun nedeni Türkiye ekonomisinin aşırı derecede dışa bağımlı üretim yapısıdır. Ara malı ithalatı üretimimizde belirleyicidir. Yani, üretimde kullanılan çok sayıda hammadde yurt dışından karşılanmak zorundadır. Söz konusu durum Türkiye ekonomisinin büyümesini istikrarsızlaştırmakta ve dış denge sorununun sürdürülebilirliğini zorlaştırmaktadır. Bu durumda, ortaya çıkan açıkların ne zaman endişe yaratacağı sorusu önem kazanmaktadır. Cari açığın sürdürülebilirliğini değerlendirmek için farklı kriterler kullanılabilmektedir. Özellikle; tasarrufların yatırımları karşılayamaması, mali disiplinin bozulması, döviz kurlarının yükselmesi, üretimde dışa bağımlılık, petrol ve doğal gaz benzeri doğal kaynakların yetersizliği, dış borçların yükselmesi gibi ekonomik olgular söz konusu açıkların sürdürülebilirliğini gündeme taşımaktadır.

Türkiye ekonomisi neredeyse son 50 yıldır cari açıktan muzdariptir. Zaman zaman dış konjonktürün etkisiyle, zaman zaman da kendi yapısal ekonomik sorunlarından kaynaklı olarak cari açık vermektedir. Son dönemde ise hem bütçe tarafında görülen bozulmalar hem de döviz kurundaki yükselmeler nedeniyle üçüz açıkların sürdürülebilirliği daha çok tartışılmaktadır. Bu çalışmada da söz konusu bu soruna Türkiye özelinde temas edilecektir. Çalışma kapsamında giriş bölümünü takiben üçüz açığın teorik çerçevesine değinilecektir. Daha sonra tasarruf-yatırım açığı, cari açık ve bütçe açıkları üzerinden sürdürülebilirlik kavramı tartışılacaktır. İlerleyen bölümlerde ise Türkiye ekonomisi 
özelinde yaşanan iç ve dış denge probleminin nedenleri farklı ekonomik göstergeler dâhilinde ele alınacak ve ortaya konulan tablo üzerinden çözüm yolları sunulacaktır. Son olarak sonuç ve değerlendirme başlığıyla çalışma neticelendirilecektir.

\section{1. ÜÇÜZ AÇIĞIN TEORÍK ÇERÇEVESİ}

Dışa açık bir ekonominin genel dengesi, gelir ve harcama ilişkisine dayanan iç denge ve dış denge tarafından belirlenmektedir. İç denge, diğer bir ifade ile yurtiçi denge makul büyüme, enflasyon ve işsizlik oranlarında hem kamunun hem de özel sektörün gelir ve harcamalarının birbirine denk olmasıdır. Dış denge ise, diğer ülkeler ile gerçekleştirilen mal ve hizmet ticaretinin eşitlenmesi olarak tanımlanabilir (Aydın ve Beşballı, 2018: 7). Ekonominin temel amacı iç ve dış dengenin sağlanması olmakla birlikte çoğunlukla bu üç dengede açık gözlenmektedir. Dışa açık bir ekonomide aynı dönemde bütçe açığı, cari açık ve özel kesim tasarruf-yatırım açığının meydana geldiği ve birbirini etkilediği durum ise üçüz açık olarak adlandırılmaktadır. Üçüz açık hipotezi, ikiz açık hipotezinin geliştirilmesi ile ortaya çıkmış olup dışa açık bir ekonomide basit Keynesyen modelde milli gelir hesaplamasına dayanmaktadır. Dışa açık bir ekonomide $\mathrm{t}$ dönemindeki milli gelir denklemi (1) numaralı eşitlikte gösterilmektedir (Dornbusch vd., 2011: 26; Carranza, 2002: 99).

$$
Y=C+I+G+(X-M)
$$

Kapalı bir ekonomide $Y=C+I+G$ iç talebi temsil etmektedir. Bu denklem, $Y=C+S+T$ olarak da ifade edilebilmektedir. Denklemde $Y$ milli geliri, $C$ tüketimi, $I$ yatırımları, $G$ kamu harcamalarını, $S$ tasarrufu, $T$ kamu gelirlerini, $X$ mal ve hizmet ihracatını, $M$ mal ve hizmet ithalatını temsil etmektedir.

Bu bilgiler ışığında denklemler birbirine eşitlendiğinde (2) nolu eşitliği elde edebiliriz.

$$
Y=C+I+G+(X-M)=C+S+T
$$

(2) nolu denklemin tekrar düzenlenmiş hali (3) numaralı eşitlikteki gibi gösterilmektedir.

$$
S+T+M=I+G+X
$$

Buradan (4) numaralı eşitlik elde edilmektedir.

$$
\text { iç denge } \underbrace{(\mathrm{T}-\mathrm{G})+(\mathrm{S}-\mathrm{I})=(\mathrm{X}-\mathrm{M})}_{\text {diş denge }}
$$

Elde edilen (4) numaralı eşitlikte $X-M$ net ihracatı, $T-G$ bütçe açığını, $S-I$ tasarruf-yatırım açı̆̆ını göstermektedir. Özel kesim tasarrufları ve yatırımları arasındaki fark (S-I) ile kamu kesimi gelir ve giderleri arasındaki farkın $(T-G)$ toplamı cari dengeye $(M-X)$ eşittir. Eşitlikten kastedilen özel kesim yatırımları, kamu harcamaları ve ihracat toplamının; özel kesim tasarrufları, vergiler ve ithalat toplamına eşit olmasıdır (Subaşat, 2010: 6). Denklem (4)'ten takip edilebileceği gibi $(T-G)+(S-I)$ iç 
dengeyi ifade ederken, $(X-M)$ ise dış dengeyi ifade etmektedir. Bir ekonomide bütçe açığına bağlı olarak cari açık meydana geliyorsa söz konusu ekonomide ikiz açık yaşanmaktadır. Bu ikiz açığa, tasarruf yatırım açı̆̆ının eşlik etmesi durumunda ekonomide üçüz açık ortaya çıkmaktadır.

Buna göre; $X<M$ durumunda cari açık (dış ticaret açığı) söz konusudur. Açığın finansmanı yabancı sermaye yatırımları, portföy yatırımları ve borçlanma ile sağlanmaktadır. $X>M$ ise ülke cari fazla veriyordur. $S<I$ durumu özel kesim tasarruf-yatırım açığını göstermektedir. Açık borçlanma yoluyla karşılanmaktadır. $T>G$ bütçe fazlası; $T=G$ bütçe denkliği (kamu kesimi tasarruf-yatırım dengesi); $\quad T<G$ bütçe açığını göstermektedir. Açı̆̆ın finansmanında yine borçlanmaya başvurulmaktadır (Eğilmez, 2009: 186).

Grafik A. Tasarruf-Yatırım Dengesi

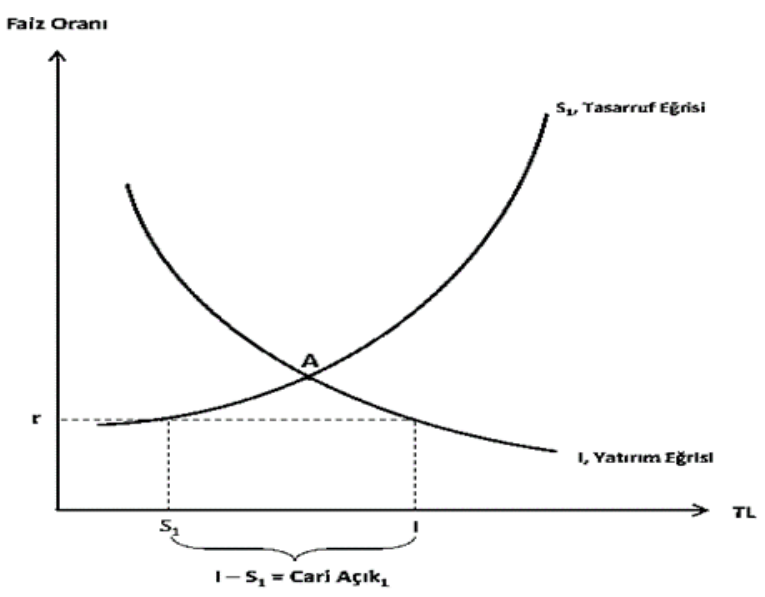

Grafik B. Tasarruf Eğrisinin Kayması

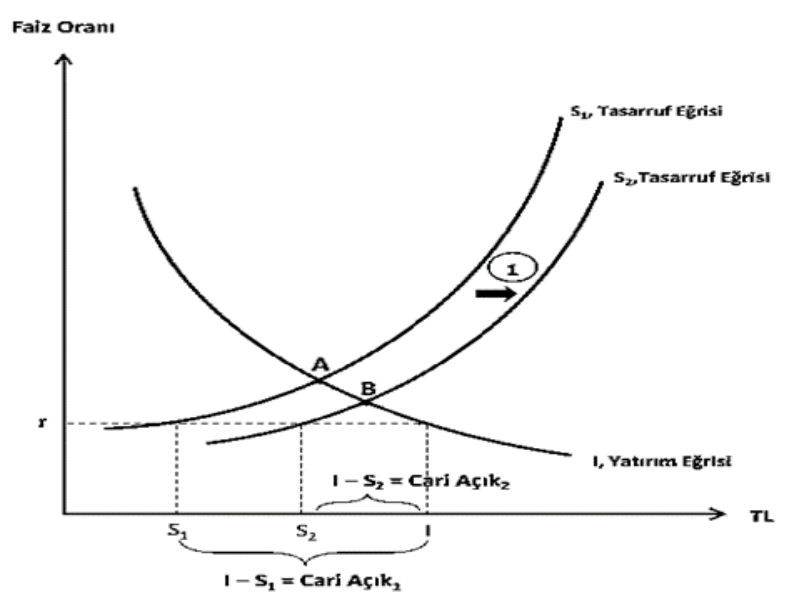

Kaynak: Baş̧, 2013: 14-15.

Tasarruf-yatırım dengesini grafik aracılığıyla da ele alabiliriz. Buna göre Grafik A, dışa açık ekonomide $\mathrm{r}$ faiz oranında tasarruf ve yatırım eğrilerinin denge noktasını ve cari açık düzeyini temsil etmektedir. A noktasında $r$ faiz oranı seviyesinde cari açık, yatırım ve tasarruf eğrileri arasındaki farka eşittir. Cari açık döviz cinsinden yükümlülüklerin artmasına ve sonunda sürdürülemez olmasına yol açmaktadır. Grafik B ise, tasarrufların artması durumunda cari açık düzeyinde meydana gelen değişimi göstermektedir. Tasarruf düzeyindeki artış S1 eğrisinin S2 konumuna gelmesi ile tasvir edilmiştir. Yeni tasarruf düzeyinde tasarruf-yatırım dengesi B noktasında gerçekleşmiştir. B noktasında cari açık düzeyi I-S2 düzeyine gelmiştir. Diğer bir ifadeyle, yeni cari açık düzeyi S2-S1 düzeyi kadar azalmıştır. Buna göre, aynı faiz oranı seviyesinde tasarruf oranlarının artması borçlanma ihtiyacını azaltarak cari açığın düşmesine yardımcı olmaktadır (TCMB, 2015).

\section{SÜRDÜRÜLEBILLİLIK KAVRAMININ İÇ VE DIŞ EKONOMIK DENGE AÇISINDAN DEĞERLENDİRILMESI}

Sürdürülebilirlik kavramının kullanım alanı oldukça geniştir. Söz konusu kavram çevre, kaynak kullanımı, tarım ve ekonomi olmak üzere pek çok alanda karşımıza çıkmaktadır. Sürdürülebilirlik; kendimize sağladığımız ortalama yaşam kalitesini potansiyel olarak tüm gelecek nesiller tarafından 
paylaş1labilecek şekilde yönetme gereksinimi olarak tanımlanmaktadır (Asheim, 1994: 1). Bir başka tanıma göre sürdürülebilirlik, ödünç alınan kaynakların geri ödenebilmesi için gereken şartların oluşturulması olarak tanımlanmıştır (Subaşat, 2010: 8). Genel anlamda ise sürdürülebilirlik, mevcut koşulların devam ettirilebilme gücü ve yeteneğidir. Literatürde sürdürülebilirlik denilince ilk karşımıza çıkan kavramlardan biri cari açığın sürdürülebilirliğidir. Aynı zamanda, tasarruf-yatırım açığı ve bütçe açığı da sürdürülebilirlik kavramıyla ilişkilendirilmektedir.

Milesi-Ferretti ve Razin (1996), cari açığın gayri safi milli hasılaya oranı \%5'in üzerinde seyrediyorsa ve bu açık kısa vadeli borçla ya da döviz rezervi ile finanse ediliyorsa ve aynı zamanda yüksek tüketim harcamalarını yansıtıyorsa cari açıkların sürdürülebilirliğinde bir tehlike sinyali olarak değerlendirmiştir. Uygur (2012) ise, cari açığın sürdürülebilirliğini üç farklı şekilde dile getirmiştir. Birincisi, mevcut uygulamalar ve politikalar borcun geri ödeme koşullarına uyum gösteriyorsa cari açığın sürdürülebilir olduğu ifade edilebilir. Bununla birlikte, (M - X = S - I) eşitliğine bağlı olarak hükümet politikaları sürdürülebilir olduğu varsayımı altında tasarruf, yatırım, ithalat, ihracat, döviz kurunun gidişatı hakkında tahmin yapmak mümkün değildir. İkincisi, mevcut durumda hükümet politikaları ile tasarruf, yatırım, ithalat ve ihracat seviyeleri ileriki dönemde bir krize ve önemli politika değişimlerine yol açacaksa bu durumda cari açıkların sürdürülebilir olduğundan söz edilemez. Hükümet politikalarının sürdürülebilir olduğu durumda da bir dış şoka bağlı olarak cari açığın sürdürülebilirliği ortadan kalkabilir. Ayrıca cari açığın kaynağı da sürdürülebilirlik açısından önem taşımaktadır. Tüketimin yükselmesi ve tasarrufun azalması sonucu ortaya çıkan cari açık yatırımların artması sonucu oluşan açıktan daha fazla dikkate değerdir. Üçüncüsü ise borcun vadesi ile ilişkilendirilmektedir. Kısa vadeli borçlanma arttıkça sermaye hareketlerinde kısa vadeli çekilmeler ekonomik bunalıma yol açarak sürdürülebilirlik için tehlike oluşturmaktadır. Öte yandan cari açık doğrudan yabancı yatırımlarla finanse edilirse sürdürülebilirliği artacaktır.

Üçüz açı̆̆ın bir diğer bileşeni ise bütçe açığıdır. Bütçe açığının özel tasarrufları emdiğini, iç yatırım için çok az şey bıraktığı bilinmektedir (Wray, 2006: 3). Aynı zamanda, kısa dönemde bütçe açıkları tüketicilerin harcamalarını teşvik ederek ithalatı özendirmekte ve dolayısıyla ticaret açığını daha da artırmaktadır (Chinn, 2005: 27). Bütçe açıklarının kalıcı bir hal alması sonucunda iç borçlanmaya yönelinmesi, iç tasarrufları özel kesimden çekerek kamuya aktarılmasına yol açabilmektedir. Yabancı kaynaklara başvurulması durumunda ise döviz kuru şoklarına maruz kalınabilir. Ülke ekonomileri bu türden şoklara maruz kaldıkları için oluşan iç ve dış açıkların sürdürülebilirliği daha da önem kazanmaktadır.

Türkiye'de de en çok tartışılan konuların başında gelen cari açık, belli bir seviyenin aşılması durumunda kriz yaratacağı varsayımına dayalıdır. Bu varsayımın temelinde ise 1994 ve 2001 krizlerinde cari işlemler açı̆̆ının milli gelire oranının \%3,5 - \%4 düzeylerine ulaşması yatmaktadır. Bundan dolayıdır ki, cari işlemler dengesinin sürdürülebilirliğinin ölçüsünde bu seviyeler eşik nokta olarak kabul edilmiştir. Öte yandan tek başına cari açığın belirli bir eşik düzeyine gelmesi 
sürdürülebilirlik açısından tek başına yeterli bir ölçüt olmayabilir (Erbaykal, 2007: 82). İç ve dış açıkların sürdürülebilirliği üzerine literatürde çok sayıda gösterge bulunmaktadır. Buna göre; tasarrufyatırım dengesi, dış ticaret dengesi, cari açık kompozisyonu, bütçe dengesi, dış borç stoku, doğal kaynaklar, döviz kurlarının seviyesi, döviz rezervleri, doğrudan ve dolaylı yabancı sermaye yatırımları ve iktisadi büyüme söz konusu göstergeler arasında sayılabilir.

\section{TÜRKIYY'DE MAKROEKONOMIK DENGENIN SAĞLANMASINA YÖNELIKK ZORLUKLAR}

Üçüz açığa genelde iç tasarrufları yetersiz olmasına rağmen potansiyelinin üzerinde büyümeyi hedefleyen ekonomilerde rastlanmaktadır. Oysa ekonomi politikalarında temel hedef iç ve dış dengeyi aynı anda sağlamaktır. Cari açığın sürekli yükseliş eğiliminde ve sürdürülemez boyutlara ulaştığı ekonomilerde büyüme, enflasyon ve işsizlik başta olmak üzere, birçok makroekonomik göstergede sorunlar ortaya çıkabilmektedir (Altunöz, 2018: 116). Türkiye ekonomisinin de uzun yıllardır muzdarip olduğu ekonomik sorunların başında cari açık ve ona bağlı olarak tasarruf yetmezliği sorunu gelmektedir. Son yıllarda, bütçe açığının da bu göstergelere eklenmesi cari açıkla birlikte üç değişkenin sürdürülebilir olup olmadığını gündeme getirmiştir.

Şekil 1'de Türkiye ekonomisinin son yirmi yıllık dönemine ait cari denge, bütçe dengesi ve tasarruf-yatırım dengesi sunulmuştur. İlgili dönemde Türkiye'nin üç makroekonomik denge bakımından da iniş ve çıkışlar yaşadığı görülmektedir. Buna göre, cari açık ve bütçe açığı değerlerinin 2000'li yılların başlarında birbirine zıt bir biçimde hareket ettiği görülmesine rağmen, küresel finans krizinde yaşanan ekonomik daralmaya bağlı olarak 2009 y1lında cari açıkta bir miktar kapanma görülmüştür. Cari denge bakımından Türkiye'nin sadece 2001 ve 2009 yıllarında cari fazla verdiği görülürken; aynı yıllarda tasarrufların yatırımlardan fazla olduğu da göze çarpmaktadır. Bütçe dengesinin 2001 krizinden sonra toparlandığı ve uzun süre istikrarlı bir şekilde denge düzeyine yakın hareket ettiği görülmektedir. Öte yandan son birkaç yılda bütçe açığının artışa geçtiği görülmektedir.

Bir ülkenin cari açık kırılganlığında cari açık/GSYİH oranının rakamsal düzeyinin yanı sıra, cari açığın yurtiçi tasarruf ve yatırımlara oranları da belirleyici rol oynar. Yatırım ve tasarrufun GSYİH'ya oranları sırasıyla $\% 15$ ve $\% 10$ olan bir ülkenin, bu oranların $\% 30$ ve $\% 25$ olduğu başka bir ülke ile kırılganlık düzeyleri aynı olmayacaktır. Bu hesaplamaya göre iki ülkenin de cari açık oranları \%5 iken, cari açığın yurtiçi tasarruflara oranı sırasıyla \%50 ve \%20 olmaktadır. Dolayısıyla, aynı cari açık oranına sahip iki ülkeden daha düşük tasarruf düzeyine sahip olan daha yüksek bir kırılganlıkla karş1 karşıya kalmaktadır (Benzer bir hesaplama için bkz. Kalkınma Bakanlığı, 2014: 8). Bu durum cari açığın oluşmasında ve sürdürülebilirliği noktasında tasarrufların önemini ortaya koymaktadır. 
Şekil 1. Cari Açık, Bütçe Dengesi, Tasarruf ve Yatırımlar (\%, GSYİH)

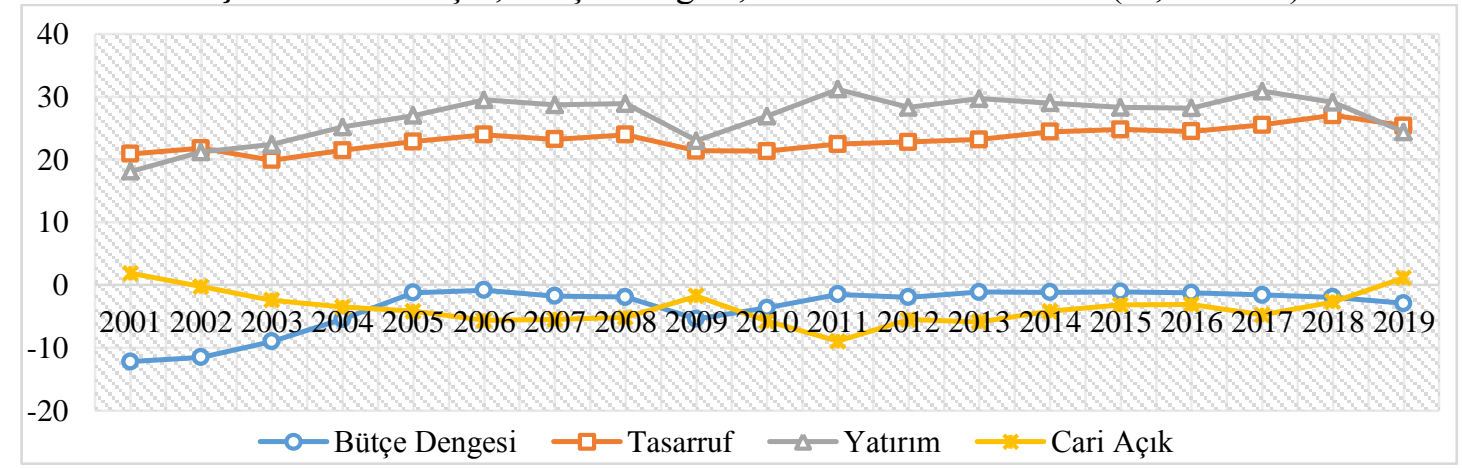

Kaynak: T.C. Hazine ve Maliye Bakanlığı, World Bank (WB)

$\mathrm{Bu}$ noktada cari açığın nedeninin tespiti için tasarruf ve yatırım düzeylerinin karşılaştırılması gerekecektir. Buna göre Şekil 1'de, 2001-2009 dönemi için tasarruf ortalaması \%22,1 iken yatırım ortalamas $\% 24,8$ 'dir. Diğer yandan 2010-2019 dönemi için de tasarruf ortalaması \%24,1 iken, yatırım ortalaması \%28,6 dolaylarındadır. Türkiye'de yaklaşık son 10 yıldır yatırımlar ile tasarruflar arasındaki fark tasarruflar aleyhine bozulmuştur. Diğer bir deyişle, son 10 yılda tasarruflardaki düşüşe bağlı olarak yatırımlar ile tasarruflar arasındaki fark açılmıştır. Bu durumda, cari açıkta oluşan artışın temel nedeni tasarruf düzeyinin yetersizliğinden kaynaklanmaktadır. Bütçe tarafındaki gelişmeler ele alındığında ise nispeten daha iyi bir görünüm ortaya çıkmaktadır. 2001-2009 döneminde bütçe ortalama \%5,4 dolaylarında açık verirken, 2010-2019 döneminde ortalama \%1,8 oranında açık vermiştir. Ancak son birkaç yılda bütçe tarafındaki bozulmalar artmaya başlamıştır. Bütçe açı̆̆ı 2019 yılında GSYIH'nin \%3'üne yaklaşmıştır.

İhracata yönelik yatırımlar nedeniyle ortaya çıkan cari açık, ileride ihraç malı üretimini artıracağından ihracatta artış meydana gelecektir. Bu durum makroekonomik dengeler açısından önemli bir tehlike arz etmeyecektir. Bununla birlikte, tasarruf düşüşünden kaynaklanan cari açık, ülkenin dış borç stokunun sürdürülemez bir hale gelmesine neden olacak ve dolayısıyla ekonomik krizleri tetikleyebilecektir (Doğan ve Tunalı, 2012: 20).

Şekil 2. İhracat ve İthalat Miktarları (ABD Doları, Milyon)

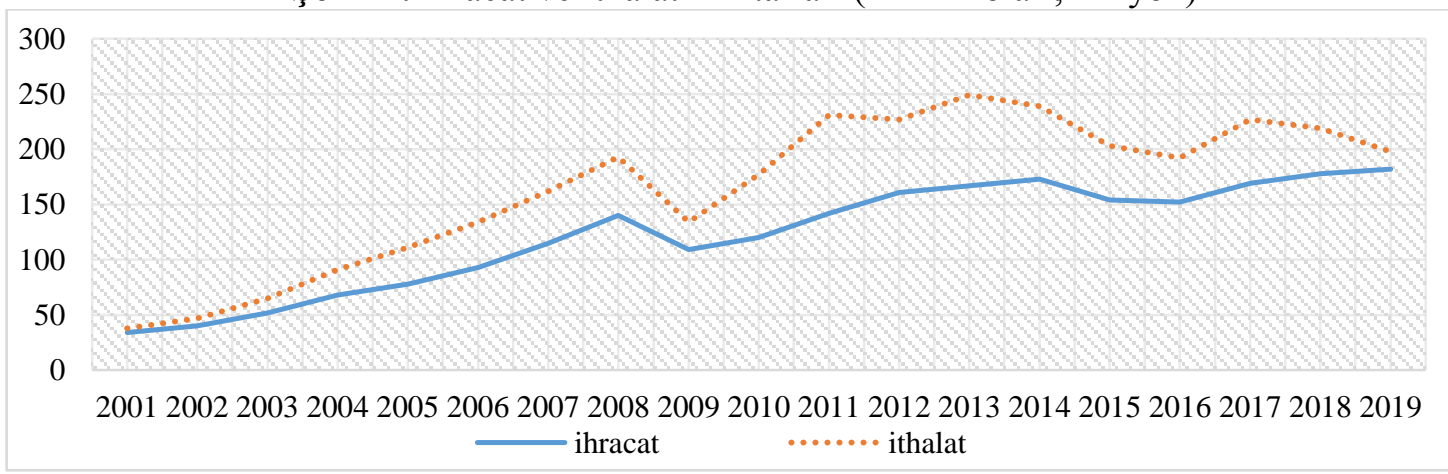

Kaynak: Türkiye Cumhuriyet Merkez Bankası (TCMB)

Diğer taraftan, ithalatın daha çok gelirden, ihracatın ise döviz kurlarından en çok etkilendiği varsayılacak olursa, 2001 krizinde cari açığın kapanması şaşırtıcı olmayacaktır. 2001 krizinden sonra 
ekonomik canlanmanın yeniden başlamasıyla ithalatın hızla arttığı, ihracattaki büyümenin ise ithalat artışını karşılayamadığı görülmektedir. Küresel finans krizinde daralan dış ticaret hacmi Türkiye'nin hem ihracatını hem de ithalatını düşürmüştür. Küresel finans krizinden sonra ithalat hızlı bir şekilde toparlanırken, ihracat ancak üç yıl sonra eski seviyesine ulaşabilmiştir. İthalattaki bu hızlı artış ekonominin hızlı bir şekilde büyümesinden kaynaklanmıştır. Ancak bu dönemde döviz kurları büyümenin ithalata verdiği desteği vermemiştir (Sezgin vd. 2015: 229). 2001, 2009 ve 2019 yılları büyümede sorun yaşanan kriz yılları olarak görülmektedir. Bu bakımdan söz konusu yıllarda cari işlemler açığının kapanması sorunun çözüldüğü anlamı taşımamaktadır. Şekil 2'de söz konusu gelişmeler 2001-2019 dönemi için sunulmuştur. Buna göre Türkiye'nin dış ticaret hacminin artış eğiliminde olduğu görülmesine rağmen ihracat-ithalat dengesi 2001-2019 dönemi boyunca açık vermiştir. Hızla genişleyen ithalat ile durgun ve rekabetçi olmayan ihracat sektörleri arasındaki boşluk, cari açığın zaman içinde sürdürülemez bir hale gelmesine neden olmaktadır. İhracat yükseldikçe ithalat daha da yükselmekte ve bu da cari açığın daha çok artmasına neden olmaktadır. Bu yüzden de ihracatın ithalatı karşılama oranı genellikle düşük çıkmaktadır.

Şekil 3. İhracatın İthalatı Karşılama Oranı (\%)

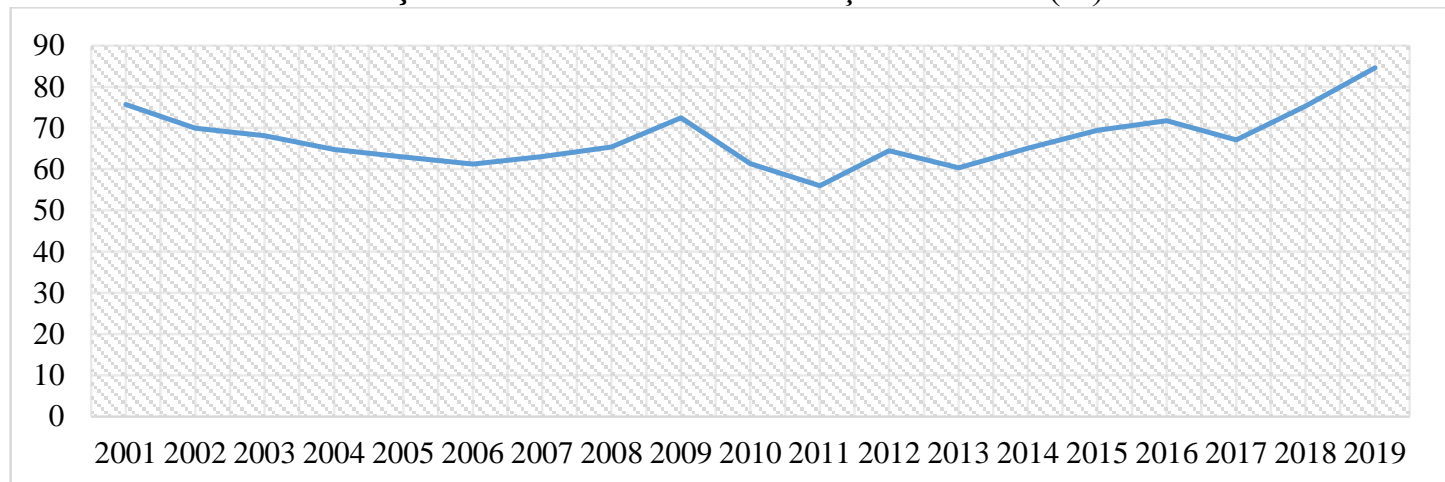

Kaynak: TÜİK resmi web sayfası

Şekil 3'te Türkiye'de ihracatın ithalatı karşılama oranının yıllar itibariyle seyri gösterilmiştir. Türk dış ticaretinde bu oran son birkaç yıl dışında genelde \%70’ler seviyesindedir. Bu oran ülkeye yeterli dövizin kazandırılması ve dış ticarette sağlıklı bir denge kurulması bakımından önemlidir. Çünkü özellikle ara malı üretiminde ithalata bağımlı olmamız ekonomik dengesizliği artırmaktadır. Öte yandan Türkiye'deki cari açık meselesi bir kısır döngü üzerinden tartışılmaktadır. Tartışmalar son dönemde daha çok TL’nin aşırı değerli olup olmadığı üzerinden gitmektedir. Öncelikli olarak aşırı değerli bir döviz kurunun ihracatı azaltması beklenir. Ancak Türkiye'de ihracatın, 2002-2008 arasında büyük bir artış gösterdiği görülmektedir. 2002-2008 döneminde Türkiye ihracatını neredeyse üç katına çıkarmıştır. Yine aynı dönemde ithalatta da benzer bir artış görülmüştür. 2010 yılından itibaren ise TL yabancı paralar karşısında değer kaybetmesine rağmen ihracat o denli artmamıştır.

Türkiye'nin mevcut ekonomik yapısı ihracata dönük üretimdir. İhracatı artırmak amacıyla verilen her türlü teşvik dolaylı olarak ithalatı da artırmaktadır. Çünkü üretimin gerçekleşmesi büyük ölçüde ithalata bağımlıdır. Kritik husus ise söz konusu bu fasit daireden çıkılması ve ithalata dayalı 
olmayan bir ihracat yapısının oluşturulmasıdır. Bu noktada yüksek katma değerli malların ihracatı önem kazanmaktadır. Katma değeri yüksek mal üretimi için gereken teknolojik dönüşüm sağlanmalıdır (Geçer, 2018: 82-83).

Şekil 4. Türkiye ve OECD Ülkelerinde Teknoloji Düzeyine Göre Sanayi Üretimi (\%)

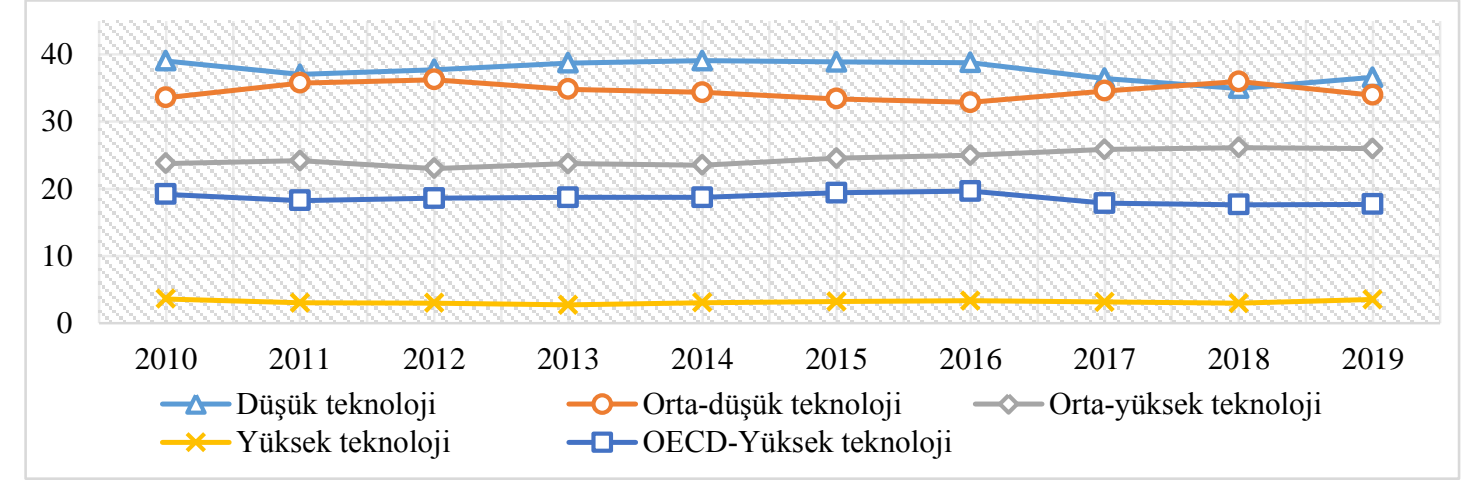

Kaynak: TÜİK resmi web sayfası, WB

Şekil 4'te de, 2010-2019 dönemi için Türkiye imalat sanayiinde ihracatın teknoloji yoğunluğunun dağılımı verilmiştir. Günümüzde ürünler teknoloji bakımından genellikle yüksek teknolojili ve düşük teknolojili ürünler şeklinde farklı gruplarda ele alınmaktadır. Buna göre, toplam imalat sanayi ihracatında yüksek teknoloji içeren ürünlerin payı 2010 yılında \%3,6 olurken, 2019'da bu oran \%3,5 seviyesinde kalmıştır. Bu veriler 1şığında, toplam imalat sanayi ihracatı içinde yüksek teknolojili ürünlerin payının hemen hemen aynı kaldığı görülmektedir. Orta-yüksek teknolojili ürün ihracatının payı ise $\% 25$ 'ler düzeyinde seyretmişken, en yüksek payı düşük teknolojili ürünler almıştır. Yani, 2010-2019 döneminde imalat sanayi ihracatı içinde en düşük pay yüksek teknolojili ürünlerde olurken, en yüksek pay düşük teknolojili ürünlerde olmuştur. OECD ülkelerinde ise yüksek teknolojili ürünlerin sanayi üretimi içindeki pay1 \%20 seviyesindedir. Türkiye'nin bu noktada OECD ülkelerinin gerisinde olduğu görülmektedir. Türkiye'nin dış açık problemini çözmesi için göreli dezavantajlarından kurtulması gerekmektedir. Bu dezavantajlardan bir diğeri de enerji giderleridir.

Şekil 5. Türkiye'nin Enerji Hariç Cari Açık Dengesi (\%, GSYİH)

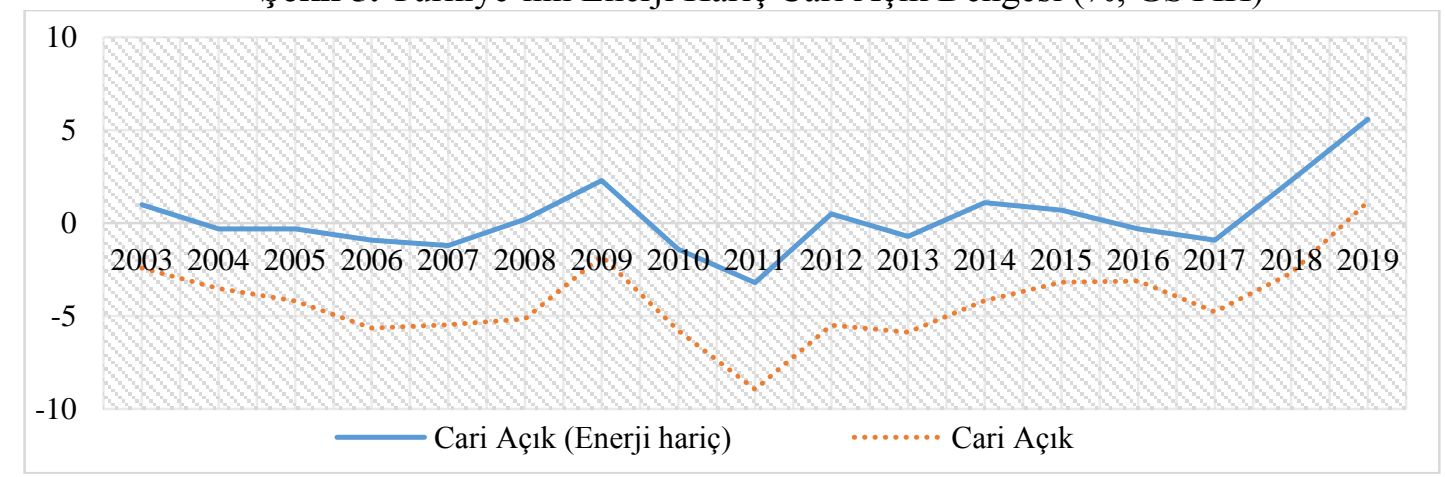

Kaynak: TCMB, T.C. Hazine ve Maliye Bakanlığı

Türkiye ekonomisi petrol ve doğalgaz başta olmak üzere enerjide dışa bağımlı bir ülkedir. Ekonomik büyümenin gerçekleşmesi ise üretimin artması ile mümkün olabilmektedir. Üretimin yapılabilmesi için öncelikle sermaye mallarının temini gerekmektedir. Türkiye ise ara sermaye 
mallarını çoğunlukla ithal ettiği için cari açık kolaylıkla kapanmamaktadır (Yanar ve Kerimoğlu, 2011: 193). Türkiye toplam ithalatından enerji ithalatını çıkarabilmesi durumunda ise cari açık önemli ölçüde azalacaktır. Ancak enerjinin talep esnekliğinin düşük olması nedeniyle, enerji ithalatının kolayca ortadan kaldırılması mümkün olmamaktadır. $\mathrm{Bu}$ da, cari açık üzerindeki enerji ithalatı baskısının kısa dönemde kaldırılmasını güçleştirmektedir (Öztürk, 2017: 562). Bundan dolayı, Türkiye'de hem enerjiye olan talebin hem de enerjide dışa bağımlılığın yüksek olması, petrol fiyatlarında meydana gelen değişime bağlı olarak cari açı̆̆g önemli ölçüde şekillendirmektedir. Enerji fiyatlarında görülen bir artış Türkiye'nin cari işlemler açığını artıracaktır (Karagöl ve Erdoğan, 2017: 364-365). Buna göre Şekil 5'te Türkiye'nin enerji dâhil ve enerji hariç cari açık dengesi sunulmuştur. Enerji harcamaları olmaksızın cari açık düzeyinin büyük oranda kapanacağı yukarıdaki şekilde net bir şekilde görülmektedir. Türkiye'nin enerji hariç cari açık düzeyi, enerji dâhil cari açık düzeyinden her daim daha dengeye yakın bir görünüm çizmekte ve bu da Türkiye için cari açığın üzerinde enerji harcamalarının büyüklüğünü ortaya koymaktadır.

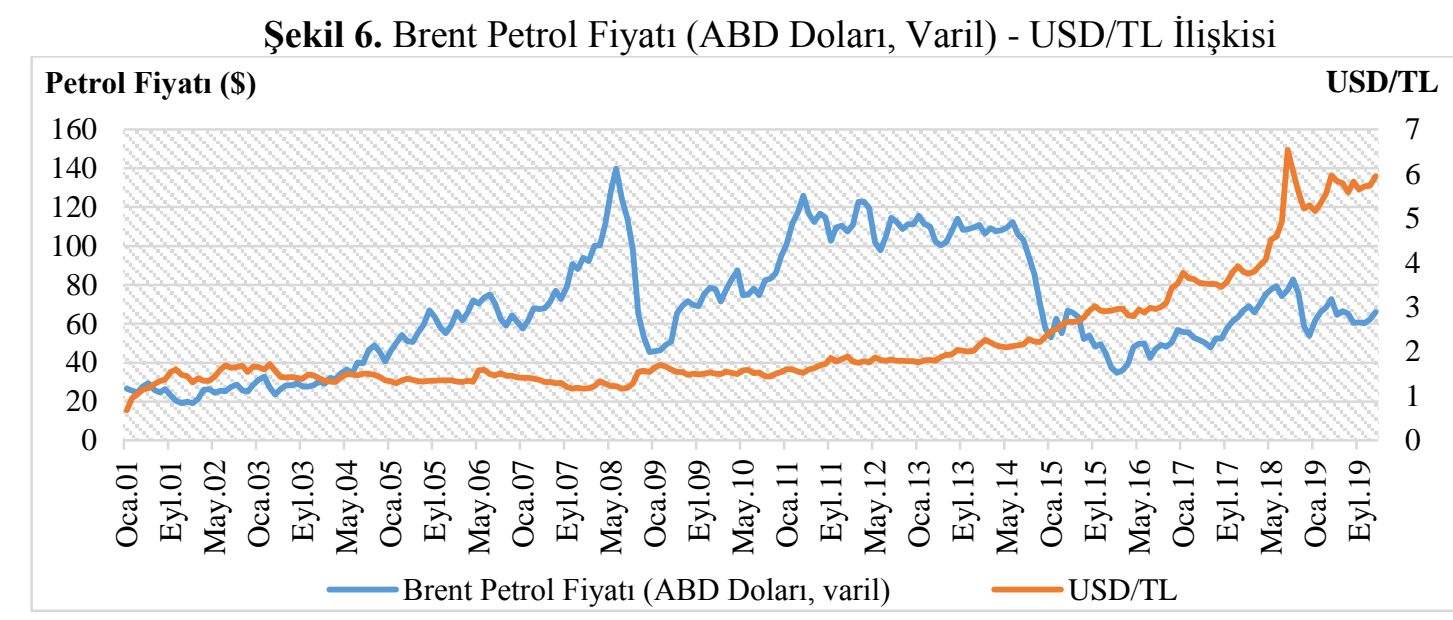

Kaynak: Investing (https://tr.investing.com/)

Öte yandan Şekil 6'da, Brent petrol fiyatı ile USD/TL kurunun son 20 yıllık seyri sunulmuştur. Buna göre, şekilde Brent petrol fiyatlarının dış konjonktürün etkisiyle dalgalı bir seyir izlediği görülmektedir. 2014 yılından sonra küresel büyümenin istenilen düzeye gelmemesi ve küresel talep daralmasına bağlı olarak petrol fiyatları düşüşe geçmiştir. Diğer yandan aynı dönemde ABD Merkez Bankası FED'in parasal sıkılaştırmaya gideceğini ilan etmesi gelişen ülke para birimlerinin değer kaybetmesine neden olmuş, Türk lirası bu dönemden sonra Amerikan doları karşısında değer yitirmeye başlamıştır.

Enerji fiyatlarındaki düşüşler, genellikle enerji kaynaklarından yoksun ve enerji ithal eden ülkelere yaramaktadır. Zira petrol fiyatlarında meydana gelen düşüşler, petrol ithal eden ülkeler için bir gelir transferi anlamına gelmektedir. Bu gelir transferinin, petrol ithalatçısı ülkelerden harcama eğilimi daha yüksek olan petrol ihracatçısı ülkelere geçmesinin ise küresel büyümeye katkı sağlaması beklenebilir (Eraydın, 2015: 9). Nitekim Türkiye'de her daim bu yönde yararlanmış ve cari açı̆̆ının 
daha da kötüleşmesinin önü alınmıştır. Bu duruma ihracat açısından yaklaşacak olursak, TL'nin son yıllarda güçlü paralar karşısında sürekli değer kaybetmesi ihracatı artırması beklenebilir. Ancak kur artışları ihraç ürünlerin cazibesini artırırken genellikle yabancı para cinsinden borcu olan ihracatçı firmaların bilançosunda olumsuz etki yaratabilmektedir. TL'nin değer kaybetmesinin negatif bilanço etkileri, pozitif rekabet etkisini bastırmaktadır. Net etki ise Türkiye için negatif olabilmektedir (Alp, 2013).

Başka bir açıdan bakılacak olursa eğer Türkiye'nin ihraç ürünlerinin pek çoğunun fiyat elastikiyetinin oldukça düşük olduğunu söyleyebiliriz. Yani, Türkiye'nin ihraç ürünlerinin fiyat avantajı bakımından rekabetçiliğinin oldukça düşük olduğunu söyleyebiliriz. Dış ticaretimizde büyük bir paya sahip olan Avrupa ülkelerinin 2007-2009 küresel finans krizinden sonra yeteri kadar toparlanamaması, Türkiye'nin ihracatını bu ülkelere uzun süre sınırlı kılmıştır. Duruma ithalat penceresinden bakacak olursak da, döviz kurlarının yükselmesi ithalat talebini azaltması beklenebilir. Özellikle, petrol ve doğal gaz gibi ithal mallara olan talep esnekliğinin düşük olması veya enerji dışında ülke içinde üretilmesi mümkün olmayan ham maddelere olan talep fazlalığı, döviz kuru artışlarından çok az etkilenmektedir. Bu ve benzeri girdilerin dövize bağlı olması Türkiye ekonomisini yabancı paralara daha fazla bağımlı kılmaktadır.

Enerji fiyatlarındaki artışlar sadece cari açık üzerinde büyük bir baskı oluşturmamakta, aynı zamanda enflasyon ve faiz gibi birçok makroekonomik değişken üzerinde etkili olmaktadır. Özellikle, döviz kurlarındaki hareketliliğe bağlı olarak petrol ve doğal gaz gibi enerji girdilerinde meydana gelen fiyat artışları maliyet enflasyonuyla bütün ekonomiyi olumsuz etkilemektedir. Enflasyondaki artışlarla birlikte fiyat istikrarının iyiden iyiye bozulması ise, faizlerdeki yükseliş ve döviz kurları üzerinden enerji girdilerine tekrardan yansımakta ve bu da bir açmaz şeklinde ekonomik faaliyetlerin yürütülmesini engellemektedir.

Şekil 7. Türkiye'nin Yenilenebilir Enerji Kurulu Kapasitesi (MW)

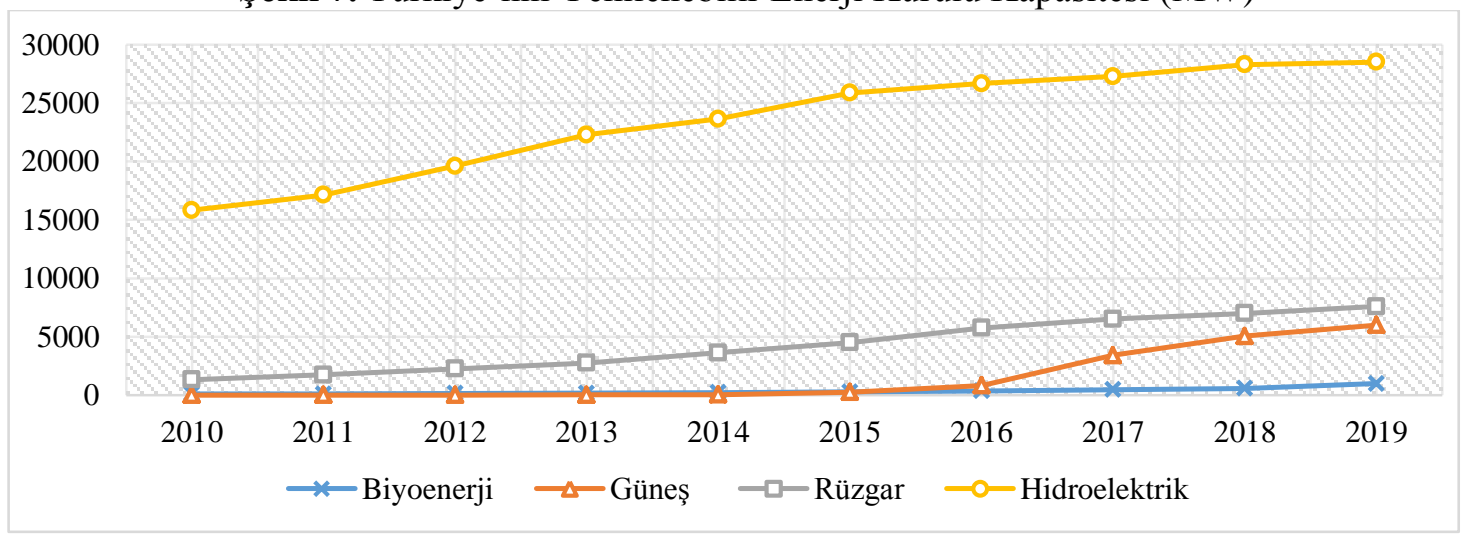

Kaynak: IRENA, Renewable Energy Statistics 2020.

Türkiye'nin enerji arzı artmamasına rağmen ekonomik büyümesine bağlı olarak enerji tüketiminin sürekli artması sürdürülebilir büyümeyi de olumsuz etkileyebilmektedir. Bu yüzden yeni ve yenilenebilir enerji kaynaklarını açığa çıkarmak cari işlemler açığını azaltmada ve sürdürülebilir bir 
ekonomik büyümeyi sağlamada iyi bir alternatif sunmaktadır. Petrol ve kömür gibi yenilenemez enerji kaynaklarının son yıllarda azalması, dünya ekonomilerini alternatif enerji kaynaklarına yöneltmiştir. Enerji giderleri yüksek olan Türkiye, son zamanlarda yenilenebilir enerji kaynaklarına olan yatırımını artırmıştır. Şekil 7'de 2010-2019 dönemi için Türkiye'nin yenilenebilir enerji kapasitesi verilmiştir. Özellikle, rüzgâr, güneş ve hidroelektrik gibi yenilenebilir enerji kaynakları kapasitesinde son y1llarda görülen artış göze çarpmaktadır. Son 10 yılda hidroelektrik kapasitesi neredeyse iki kat yükselmiştir. Türkiye'nin bulunduğu iklim kuşağı göz önünde bulundurulduğunda, hiç azalmayacağı düşünülen yenilenebilir enerji kaynakları bakımından dikkate değer bir potansiyel taşıdığı söylenebilir. Hem cari açık veren bir ülke olması hem de gelecekte bir gün tükenebilir enerji kaynaklarının azalacağı düşünüldüğünde Türkiye'nin söz konusu bu zenginliğinden daha çok yararlanması gerekecektir. Dünyada ve Türkiye'de meydana gelecek olan böylesi bir dönüşüm uzun vadede enerji sektörüyle birlikte turizm sektörüne de pozitif yansıyacaktır. Bu yüzden yenilenebilir enerji kaynaklarına daha çok yatırım yapılması orta ve uzun vadede Türkiye'nin dış ekonomik dengesine olumlu yansıyacaktır.

Şekil 8. Yabancilardan Elde Edilen Turizm Gelirleri (Milyar \$)

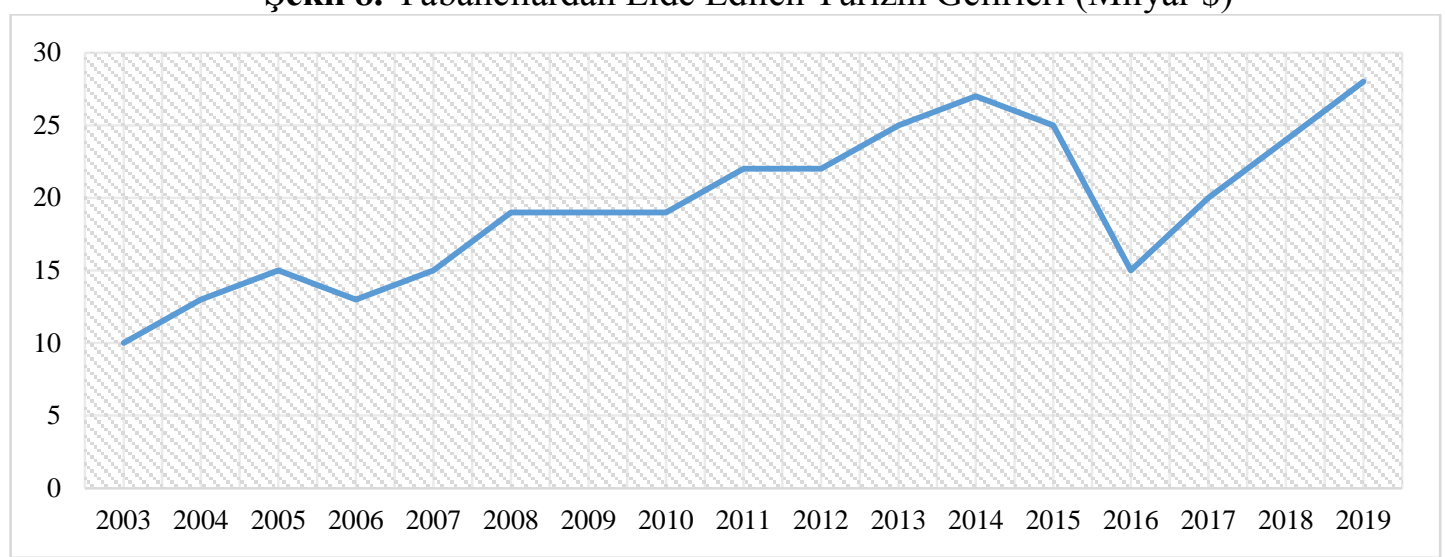

Kaynak: T.C. Kültür ve Turizm Bakanlığ 1

Dış finansman ihtiyacı yüksek olan ülkeler için turizm sektörü önemli fırsatlar sunmaktadır. Döviz gelirleri bakımından dezavantajlı olan ülkelerde turizm sektörü ödemeler bilançosunun dengeye gelmesine yardımcı olur. Türkiye'nin bulunduğu coğrafi konum itibariyle dört mevsimi yaşaması ve bunun yanında doğal alanlar ve kültürel varlıklar bakımından zengin olması turizm açısından önemli fırsatlar barındırmaktadır. Şekil 8'de 2003-2019 dönemi için yabancılardan elde edilen turizm gelirleri sunulmuştur. Buna göre, Türkiye'nin yabancılardan elde ettiği turizm gelirleri 2015 yılında TürkiyeRusya arasında yaşanan siyasi gerginlik ve 2016 yılında meydana gelen darbe teşebbüsüyle azalmıştır. Türkiye'nin turizm pazarı bu yıllarda bölgesel ve küresel bazlı iç ve dış şoklardan doğrudan etkilenmiştir. Bu gelişmelere rağmen Türkiye'nin yabancılardan elde ettiği turizm gelirlerinde bir artış trendi olduğu görülmektedir. 
Şekil 9. Cari Açık ve Doğrudan Yabancı Yatırımlar (\%, GSYİH)

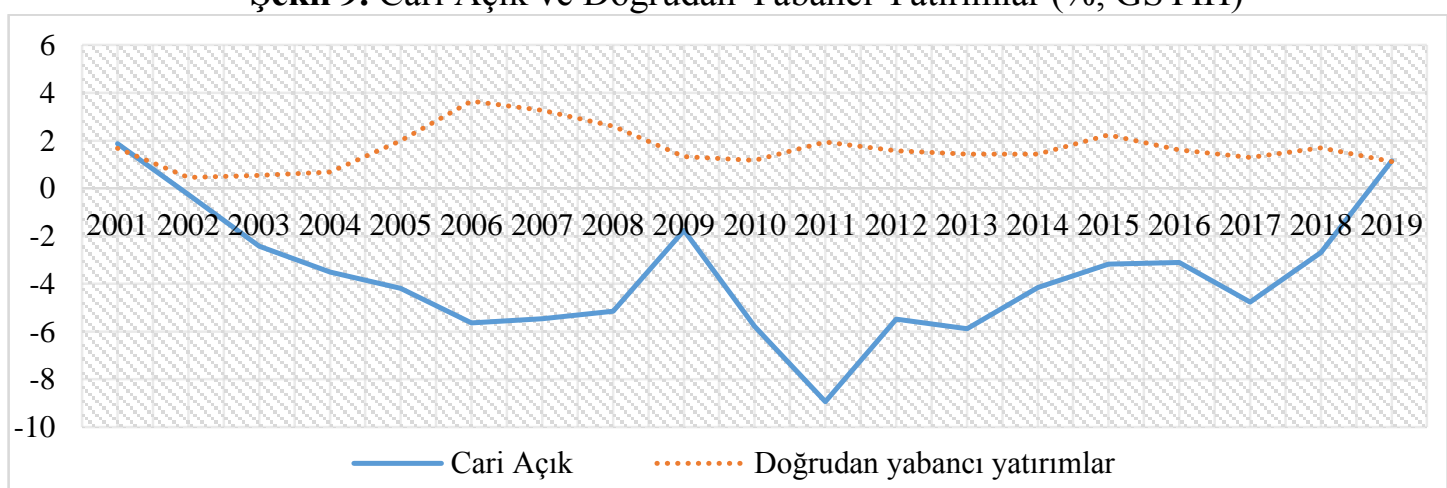

Kaynak: WB

Bir ekonomide cari açık üç şekilde finanse edilir. Bunlardan birincisi yabancı banka, hükümet ya da Dünya Bankası, IMF gibi uluslararası kuruluşlardan borç alınması yoluyladır. İkincisi doğrudan ve dolaylı yabancı yatırım yoluyla yapılan finansman yöntemidir. Üçüncüsü ise merkez bankasınca döviz rezervleri kullanılarak yapılan finansman biçimidir. Bu finansman yöntemlerinden direkt dış yatırım dışında kalan finansal sermaye girişleri borç artırıcı özelliktedir. Cari açığın doğrudan yabancı yatırımlar gibi fiziksel yatırımlar ile finanse edilmesi diğer finansman yöntemlerine göre daha tercih edilebilir bir seçenek olarak kabul edilir (Eşiyok, 2012: 67). Ancak cari açığın sürdürülebilirliği, ülkelerin ödeme gücü kapasitesi yanında uluslararası finans sisteminin borç verme koşulları ve risk iştahı da belirleyici olmaktadır (Kalkınma Bakanlığı, 2014: 7).

Doğrudan yabancı yatırımlar özellikle gelişmekte olan ülkeler açısından dış finansman kaynakları bakımından başat roldedir. Doğrudan yabancı yatırımlar alıcı ülkenin ödemeler bilançosu üzerinde direkt olumlu etkisi olan sınır ötesi bir sermaye transferidir. Ülkeye döviz girişi sağladığından cari açığın kapanmasına pozitif katkıda bulunan doğrudan yabancı yatırımların diğerlerine tercih edilebilir olmasının nedeni teknoloji ve yönetim uzmanlığı gibi olumlu dışsallıklara sahip olmasıdır (Carranza, 2002: 111). Gelişmekte olan ülkelerin dışa açılmasıyla birlikte doğrudan yabancı sermaye yatırımlarını ülke içine çekmesi ülkelerin ekonomik verimliliğine ve istihdama pozitif katkı yapacaktır. Zira ülke içinde yetersiz olan kaynaklar dışarıdan temin edildiği takdirde, atıl kapasite reel üretime daha güçlü katılacak ve bu sayede iktisadi gelişim ivme kazanacaktır. $\mathrm{Bu}$ bakımdan gelişmekte olan ülkelerin dışa açılma başarısında, reel sektörün gelişip gelişmemesine bakılır (Genç vd., 2017: 87). Bu bilgiler ışı̆̆ında Türkiye’ye gelen doğrudan yabancı yatırımların uzun yıllardır stabil biçimde hareket ettiği görülmektedir. Buna göre Şekil 9'da Türkiye'nin cari açıkla birlikte doğrudan yabancı yatırım düzeyleri verilmiştir. 2004-2007 yılları arasında yükselişe geçen doğrudan yabancı yatırımların GSYIH'y'ya oranı son 10 y1ldır \%2 dolaylarında seyretmektedir. Türkiye gibi dışa açık ve yabancı sermaye yatırımlarına bağlı olan bir ülke için bu oranın son derece düşük olduğunu söyleyebiliriz. Türkiye cari açı finansmanının çoğunu doğrudan yabancı yatırımlardan ziyade kısa vadeli portföy yatırımlarıyla karşılamaktadır. Yabancı yatırımları ülkeye çekebilmek için 
öncelikle siyasi ve ekonomik istikrar sürdürülerek yabancı yatırımcılara güven ortamı sağlanmalı ve böylece uygun yatırım ortamı yaratılmalıdır.

Şekil 10. Büyüme ve Cari Açık İlişkisi

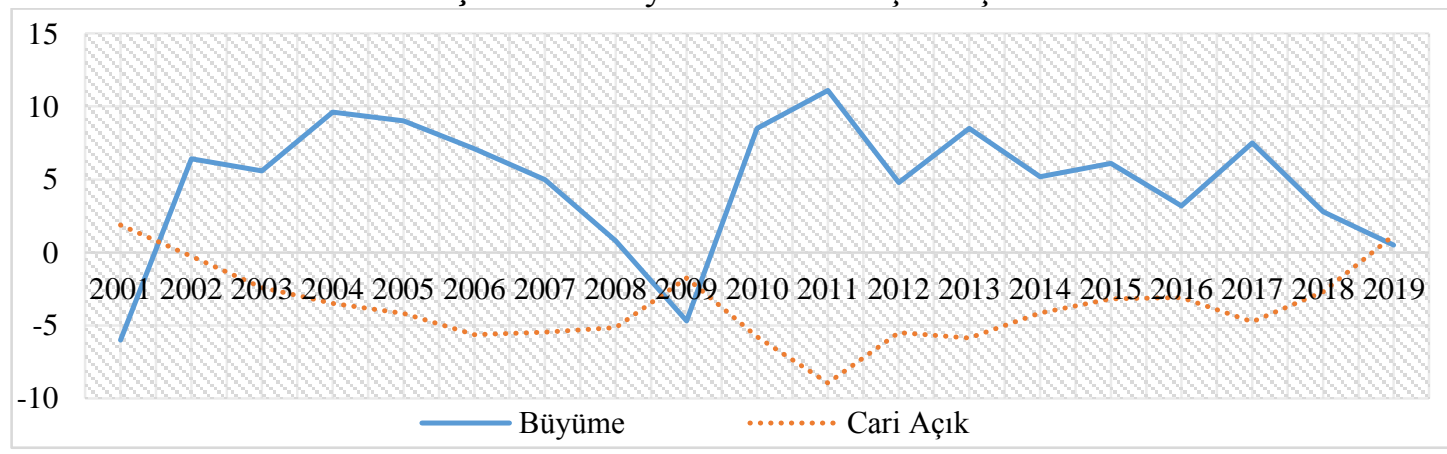

Kaynak: TÜİK resmi web sayfası, WB

Gelişmekte olan ekonomilerin birçoğu üretimlerinde yüksek oranda ithal girdi kullanımından dolayı cari işlemler dengesinde ciddi bozulmalar yaşamaktadır. Türkiye ekonomisinin de genellikle bu döngü içinde hareket ettiği görülmektedir. Cari açığın çok fazla arttığı dönemlerde yüksek büyüme rakamlarına ulaşılması, cari fazlanın verildiği kriz dönemlerinde ise düşük büyüme rakamlarının ortaya çıkması bu durumun açık bir göstergesidir. Ancak diğer taraftan Türkiye'de kısa dönemde ara malı ithalatına dayalı bu üretim yapısının değiştirilmesi oldukça zordur (Telatar ve Terzi, 2009: 133). Zira Türkiye son 50 yılda birçok kez cari açık problemi yaşamış ve yaşamaya devam etmektedir. Yaşanan ekonomik krizlerin çoğunun öncesinde cari açık dengesizliği görülmüştür. Türkiye ekonomisinde büyüme ile cari denge arasında güçlü bir bağ bulunmaktadır. Buna göre Şekil 10'da, Türkiye'nin son 20 y1llık dönemine ait ekonomik büyüme-cari açık ilişkisi verilmiştir. Söz konusu ilişkiye göre Türkiye'nin yüksek büyüme yaşadığı yıllarda cari açığının arttı̆̆ı görülmektedir. Büyüme oranlarının düşüşe geçtiği ve ekonomik daralma yaşanan yıllarda ise cari açıkta düşüş gözlenmektedir. Özellikle, 2007-2009 küresel finans krizinde küresel ekonomide yaşanan daralmaya istinaden ortaya çıkan düşük büyüme oranları cari açığı azaltmıştır. 2010 yılından sonra bir taraftan dış konjonktürün daralması diğer taraftan dış açığı azaltmaya yönelik politikalar cari açığın bir miktar kapanmasını sağlamıştır. Bu düşüşün bedeli ise, ekonomide görülen yavaşlama şeklinde kendini göstermiştir. 2017 yılından sonra ise büyümedeki düşüşe bağlı olarak cari açık daha da azalmıştır. Bu bağlamda Türkiye ekonomisinin yüksek büyüme oranlarını yakalamak için daha yüksek cari açık vermek zorunda kaldığı görülmektedir.

Cari açık ve bu açığın sürdürülebilirliğinin sağlanmasında ülkelerin ödeme gücü önem arz etmektedir. Teorik olarak ödeme gücü, bir ekonominin bütçe kısıtlamasıyla ilişkilidir. Bu anlamda bir ekonominin gelecekteki ticaret fazlasının mevcut iskonto edilmiş değeri, mevcut dış borçluluğa eşitse o ülkenin borçlarını ödeyebilir durumda olduğu kabul edilmektedir. Kamu borç sürdürülebilirliği açısından ise ödeme gücü, gelecekteki bütçe fazlasının mevcut iskonto edilmiş değerinin mevcut kamu borcuna eşit olmasıdır (Milesi-Ferretti ve Razin, 1996: 162). Yani, cari açığın borç yaratmayan dış 
kaynaklar ile finanse edilmesi durumunda cari açığın sürdürülebildiği kolaylaşacaktır. Diğer yandan, özellikle kısa vadeli ve borç yaratan dış kaynaklar ile karşılanması ise tehlike oluşturacağından cari açık sürdürülemeyen boyutlara ulaşabilir. Aynı şekilde, cari açığın sürdürülebilirliğinin ekonomilerin dış borç yükümlülüğü ve bu yükümlülüğünü ödeyebilme kapasitesiyle ilişkilendiren görüşler de mevcuttur. Bu durumun nedeni ise, cari açığın bir anlamda döviz açığını ifade etmesi ve bundan dolayı da dış borçlanma ihtiyacını doğurmasıdır (Saçık ve Alagöz, 2010: 115).

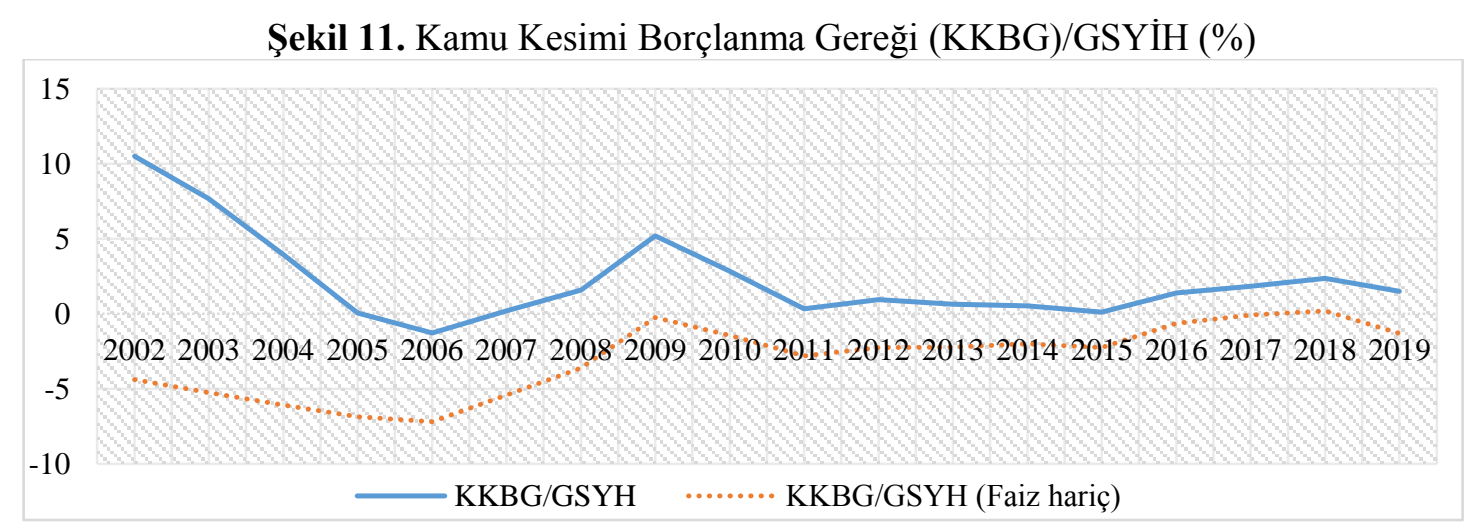

Kaynak: T.C. Cumhurbaşkanlığı Strateji ve Bütçe Başkanlığı (SBB)

Kamu kesimi borçlanma gereği ve kamu borç stoku da üçüz açığın sürdürülebilirliği tartışmasında ön plana çıkmaktadır. Şekil 11'e göre Türkiye ekonomisinin yaklaşık son 20 yıllık dönemi içinde kamu kesimi borçlanma gereğinin GSYİH'ya oranı yatay seyretmiştir. Aynı durumun faiz hariç KKBG/GSYIH'ya oranı için de geçerli olduğunu söyleyebiliriz. Ancak Şekil 11 incelendiğinde son dönemde kamu kesimi borçlanma gereğinin bir miktar artışa geçtiği görülmektedir. Aynı zamanda, kamu ve özel sektörün brüt dış borç stoku genel trendi artış göstermiştir. Kamu kesimi borçlanma gereğinin yükselmesine istinaden son dönemde kamu brüt dış borç stoku yükselişe geçmiştir. Bu durum Şekil 12'den izlenebilmektedir. İç ve dış dengenin sağlanması noktasında zorluk çeken bir ekonominin bu açıkları daha fazla borçla karşılaması ve ortaya çıkacak olan borcun da yabancı para cinsinden olması, nihayetinde artan bir kur-faiz sarmalını ortaya çıkaracaktır.

Şekil 12. Brüt Dış Borç Stoku (Milyar Dolar)

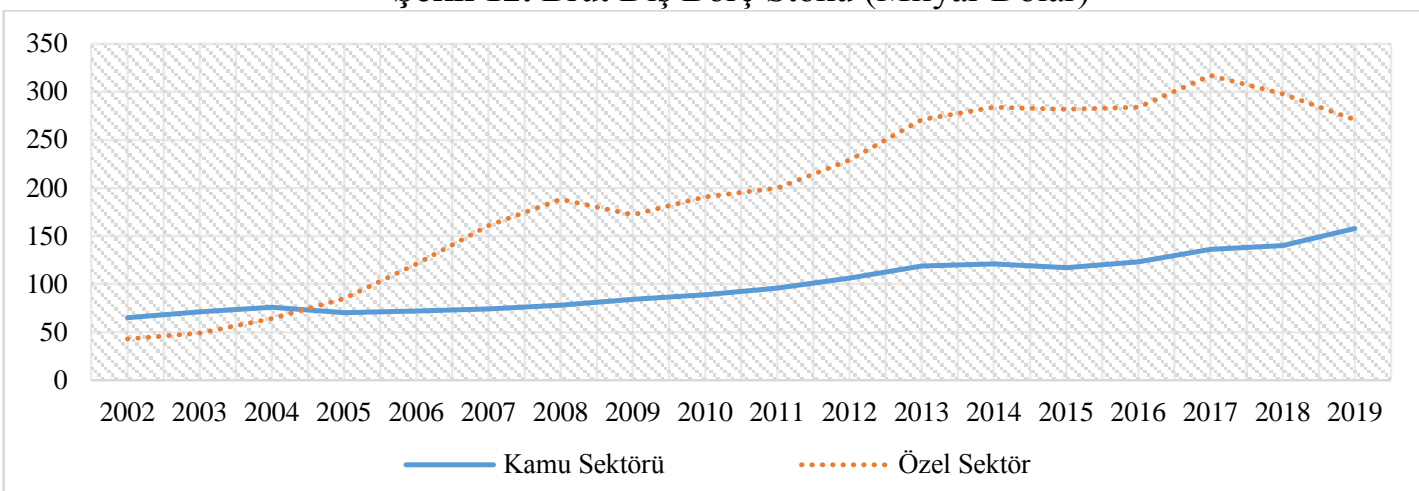

Kaynak: T.C. Hazine ve Maliye Bakanlığg

Türkiye ekonomisinin iç ve dış dengesi tarihsel açıdan da ele alınabilir. Buna göre, 1974-2002 döneminde cari açık devletin finansman açığından kaynaklanıyorken, 2003-2015 döneminde ortaya 
çıkan cari işlemler açı̆̆g ise kamu kesimi ile birlikte özel sektörün finansman açı̆̆ının sonucudur. 1974-2002 dönemi boyunca kamu sektörü finansman açı̆̆ı GSYİH'nın yıllık \%5,4’ü oranındadır. Buna mukabil özel sektör aynı dönemde GSYİH'nın yıllık \%4,1'i oranında tasarruf fazlası vermiştir. Yani 1974-2002 döneminde verilen cari açık, devletin finansman açığından kaynaklanmıştır. 20032015 dönemi boyunca ise durum tersi yönde değişmiştir. Zira 2003-2015 döneminde devletin finansman açığı bir önceki döneme göre önemli ölçüde azalarak GSYİH'nın yıllık \%1,8’i düzeyinde gerçekleşmiştir. Buna mukabil bir önceki dönemde tasarruf fazlası veren özel sektör, 2003-2015 döneminde GSYİH'nın yıllık \%2,9’u oranında tasarruf açığı vermiştir. Anlatıldığı üzere, 2003-2015 döneminde bir önceki dönemden farklı olarak üçüz açık meydana gelmiştir. Başka bir değiş ile 2003 sonrasında meydana gelen cari işlemler açığı kamu kesiminin finansman açığı ile özel sektörün tasarruf açığının bir sonucudur (Aydın ve Beşballı, 2018: 10-11). Bu veriler 1şı̆̆ında Türkiye ekonomisinin sürdürülebilirlik noktasında farklı dönemlerde farklı performans sergilediği görülmektedir.

\section{MAKROEKONOMIK DENGENIN SAĞLANMASINDA UZUN VADELİ BAKIŞ AÇISI}

Türkiye'de cari açık tartışmaları, haklı ya da haksız, son 50 yılda, özellikle de son 15 yılda, yaşanan ekonomik bunalımlarda hep gündem oluşturmuştur. Sürdürülemez boyutlara ulaşan cari açıkların ekonomide ani kur ve faiz değişmelerine sebep olması, iç ve dış borç stoku/GSYİH oranlarında sıçramaya yol açmaktadır. Kur ve faizin hızlı değişmesi de sürdürülebilirliği olumsuz etkileyebilir. Bununla birlikte, kur ve faiz oranlarındaki değişimlerin cari açıkta bir düzeltme meydana getirmesi büyümede durmaya veya gerilemeye yol açabilmektedir (Uygur, 2012: 20). Başka bir açıdan bakacak olursak eğer Türkiye, dış ticaretini ağırlıklı olarak kendi para birimi üzerinden yapan gelişmiş ülkeler gibi birtakım ayrıcalıklara sahip olmadığından döviz kurları üzerinden daha savunmasız kalmaktadır. Öyle ki, cari açık sürdürülebilir gibi görünse bile yatırımcıların bu konudaki algılarının değişmesi dış dengenin bozulmasına neden olmaktadır. Ancak Türkiye'nin ekonomik yapısı sürdürülemez gibi görünen cari açıkları sürdürülebilir kılacak potansiyeli barındırmaktadır.

Cari açığın artmasının veya azalmasının konjonktürel sebepleri mevcuttur. 2007-2009 küresel finans krizinden sonra majör merkez bankaları büyük miktarda likidite genişlemesine giderek faiz oranlarını minimum düzeylere çekmişlerdir. Bu durum doğal olarak birçok ülke için ucuz finansman olanakları yaratmıştır. Türkiye'de 2010 ve 2011 yıllarında bu finansman olanaklarından yararlanmıştır. Zamanla, ekonomilerde görülen göreceli toparlanma 2015 yılından sonra kademeli faiz artırımını gündeme getirmiştir. Ekonomileri daha çok dış finansman olanaklarına bağlı olan Türkiye gibi ülkeler için ise finansman maliyetlerinin artmasından dolayı sıkıntılı bir dönem başlamıştır. Dış finansmanda görülen dalgalanmalar neticede TL ve dövizde de dalgalanmalara neden olmuştur. Yani, dış finansmanın görece daha kolay sağlandığı dönemlerde TL değerlenirken, dış finansman olanaklarının daraldığı kriz dönemlerinde yabancı sermayenin aniden çıkışıyla birlikte döviz kurları 
yükselmektedir (Bahçekapıl1, 2015: 118). Bu bakımdan, tasarruf eksikliğinin ağırlıklı olarak sıcak para dediğimiz yabancı kaynak girişiyle sağlanması ülke için risk teşkil edeceğinden, dış finansman kalitesinin sürdürülebilirliği önemli hale gelecektir. Diğer bir ifadeyle, dış dengenin sağlıklı bir biçimde sürdürülebilmesi daha çok finansman kaynaklarının niteliğiyle ilgilidir. Türkiye ekonomisini daha kırılgan bir hale getiren dış açık sorununun ana nedenlerinden birisi, üretimin ve dış ticaretin yüksek teknolojili üretim bakımından zayıf kalmasıdır. Yapısal dönüşümün sağlanması gereken yer burasıdır. Ekonomik büyümenin finansmanında önemli rolü bulunan sermaye piyasalarının sı̆̆ olması yatırımların finansmanını daha kısa vadeli kılmaktadır. Sermaye piyasalarının derinleşmesiyle yatırımların finansman kalitesinin artması, ekonomik dalgalanmaları üretim gücünden daha bağımsız k1lacaktır.

Kaliteli üretim için en başta eğitimli insan kaynağına ihtiyaç vardır. Eğitilmiş insan gücünün çoğalması uzun vadede Türkiye ekonomisinde istikrarlı bir makroekonomik dengenin oluşmasında etkili olacaktır. Türkiye'nin genç ve dinamik nüfusu bu konuda büyük bir potansiyel barındırmaktadır. Türkiye'nin Ar-Ge ve iş gücü yetkinliklerinin geliştirilmesine dönük yatırımlarının artması, uzun dönemde uzak doğudaki ve diğer başka pazarlardaki rakiplerine karş1 rekabette üstünlük sağlayacaktır. Bu yönde sarf edilen her türlü çaba ise, inşaat gibi dış ticarete konu olmayan mal ve hizmet üretiminin payının, dış ticarete konu olan mal ve hizmet üretimine kaymasına neden olacaktır.

Altı çizilmesi gereken başka bir nokta ise cari açı̆̆ı azaltmak pahasına ithal ikameci üretim tarzında bir yapıya geçmenin yanlışlığıdır. İlk bakışta Türkiye'nin dış açık probleminin sürdürülebilirliği noktasında ithalatı caydırıcı politikalarla daha düşük bir dış ticaret açığına ulaşması mümkün gözükebilir. Ancak ithal edilebilir bir ürünü dışarıdan almamak için içeride üretmeye kalkışmak kaynakların etkin kullanılmasına sekte vurup üretim maliyetlerini artırabilir. Önemli olan tüketimimizi karşılayacak üretimin aynı kalitede gerçekleştirilebilmesidir. İthalatı kısmaktan ziyade rekabet edebilirliğinin ön planda tutularak verimliliğin ve üretimin daha çok artması gerekmektedir. Hem kalitede hem de fiyatlarda dünya ülkeleriyle rekabet edebilmek uzun vadede dünya pazarına daha çok mal satabilmeyi mümkün hale getirecektir.

Türkiye ekonomisinin 1980'li yıllarla birlikte dışa açık bir sanayileşme politikası izlemesi enerji tüketimini yükseltmiştir. 2000'li yıllardan sonra ise ekonominin daha da genişlemesi ve nüfusun artması enerjiye duyulan ihtiyacı çok daha şiddetli bir hale getirmiştir. Bu yüzden gelecek yıllarda Türkiye'nin dış denge sorununu çözmek için enerji maliyetlerini düşürmesi gerekmektedir. Türkiye'nin son yıllarda yenilenebilir enerji kaynaklarına yönelmesi bu konuda atılmış önemli bir adım sayılmaktadır. Uzun dönemde dünyada petrol gibi tükenir enerji kaynaklarına ihtiyacın daha az olacağı düşünüldüğünde, Türkiye'nin şimdiden alternatif enerji kaynaklarına yönelmesi dış ticaret açığını kapatacaktır. 
Turizm gelirleri ihracat gelirinden sonra en önemli döviz kaynağıdır. Türkiye bu noktada gerek coğrafi konumu gerekse tarihi ve kültürel zenginliğiyle öne çıkmaktadır. Etkili tanıtımlar, ulaşım olanaklarının daha da geliştirilmesi ve hizmet kalitesinin artırılması sektörün sürdürülebilir olmasını sağlayacaktır. Diğer yandan, Türkiye'nin hem yurt içinde hem de bölgesinde barış ortamını sağlanmasında güçlü bir rol alması, turizm gelirlerinin krizlerden en az etkilenecek biçimde sağlam bir zemine oturmasını sağlayacak ve Türkiye'yi dış şoklara karşı daha dirençli kılacaktır (Beyaz ve Karabacak, 2018).

İç ve dış dengenin sağlanması noktasında kamu harcamalarının kısılarak kamu mali disiplinin tesis edilmesi fayda sağlayacaktır. Bu kapsamda, piyasa mekanizmasının etkin olarak işlemesi iç ve dış açıklar üzerinde pozitif etkiler yaratabilmesini mümkün kılabilecektir. Aynı şekilde, kamu kesimi tasarruflarının artırılması noktasında tedbirler alınması gerekmektedir. Burada vurgulanması gereken nokta; alınacak tedbirlerin piyasaların işleyişini aksatmayacak bir şekilde ve tarafsız maliye anlayışının gereklerini taşımasıdır. Öte yandan, yatırımların ithalata olan duyarlılığının azaltılmasının üzerinde durulması, dış açıkların negatif etkilerini hafifletecektir. Ekonomik ve siyasi istikrara paralel olarak dış tasarrufların ülkeye çekilmesiyle birlikte ekonomik denge olumlu etkilenecektir. Ekonomik dengenin tam olarak sağlanabilmesi noktasında ise kaynakların optimum dağılımının sağlanabilmesi gerekmektedir. Piyasa mekanizmasının etkinliğinin artacağı böylesi bir süreçte, makroekonomik dengeleri bozmaksızın gerçekleştirilecek politika uygulamalarının ekonomik dengeye olumlu yansıması beklenecektir (Akınc1 vd. 2016: 42).

Dünya pazarında rekabet şartları gün geçtikçe zorlaşmaktadır. Geleneksel yöntemlerle gerçekleşen üretim tarzıyla oluşturulan bir ekonomik yapı küresel düzlemde önemli bir yer edinmeyi zorlaştıracaktır. İnovasyona ağırlık vermek dış açıkların kapanmasına yardımcı olacaktır. Bu bağlamda son yıllarda gittikçe önemli hale gelen; bilişim, finans, yapay zekâ, uzay, yenilenebilir enerji, e-ticaret, taşımacılık-lojistik, çevre, ilaç, tarım ve gıda gibi teknoloji yoğun alanlarda atılacak güçlü adımlar Türkiye'nin dış bağımlılıktan kurtulmasına yardımcı olacak ve dolayısıyla makroekonomik kırılganlıkları azaltacaktır.

\section{SONUÇ VE DEĞERLENDİRME}

Bir ülkede cari açık, bütçe açığı ve tasarruf-yatırım açığının aynı anda görülmesi üçüz açık olarak adlandırılmaktadır. İç ve dış ekonomik dengeyi korumak, başta gelişmekte olan ülkeler olmak üzere, çok sayıda ülkenin karşı karşıya olduğu büyük bir zorluktur. Bu durumun temel nedeni çoğu ülkenin yatırım sektörlerinin büyük ölçüde çeşitli mal türlerinin ithalatına bağımlı olmasıdır.

Türkiye ekonomisi de son y1llarda iç ve dış dengedeki bozulmalarla gündeme gelmiştir. Özel kesim tasarrufların yatırımları finanse edememesi Türkiye'yi dış kaynak bulmaya zorlamaktadır. Türkiye ekonomisinin cari açık vermesinin temel nedenleri arasında enerji (petrol, doğal gaz) ithalatçısı olması, üretim yapısının ara malı ithalatına bağımlı olması, tasarruf oranlarının azlığı gibi 
unsurlar yer almaktadır. Türkiye'nin dış denge sorununu çözmek için enerji giderlerini düşürmesi gerekmektedir. Türkiye'nin son yıllarda yenilenebilir enerji kaynaklarına yönelmesi bu konuda atılmış önemli adımlardan biri sayılabilir. Ancak cari açığın, Türkiye'nin ekonomik yapısından kaynaklı olarak kriz dönemlerinde unutulması, öte yandan ekonomideki göreli iyileşmeler ile birlikte yeniden artışa geçmesi cari açıkla büyüyen bir üretim yapımız olduğunu ortaya koymaktadır. Son yıllarda, cari açı̆̆ın yanına bütçe disiplinindeki bozulmaların da eklenmesiyle söz konusu açıkların sürdürülebilirliği yeniden tartışılmaya başlanmıştır.

Türkiye'nin yatırımlarını finanse etmesi noktasında iç tasarrufların önemi büyüktür. Tasarruf hacminin artması uzun vadede dış finansman kaynaklarına olan ihtiyacı azaltacaktır. Tasarruflarla birlikte üretimin çoğalması zamanla ekonomik yapıyı daha sağlam kılacak ve doğrudan yabancı yatırımların önü açılacaktır. Dış açıkların sürdürülemez boyutlara ulaşması, hızlı kur ve faiz değişmelerine yol açacak ve neticede ekonomik büyümede istikrarsızlıklar ortaya çıkacaktır. Bu da, iç ve dış borç stokunda sıçramalara yol açmaktadır. İç ve dış dengenin sağlanması noktasında zorluk çeken bir ekonominin bu açıkları daha fazla borçlanmayla karşılamaya çalışması ve ortaya çıkan borcun da yabancı para cinsinden olması nihayetinde artan bir kur-faiz sarmalını ortaya çıkaracaktır. Dış açıkların bu şekilde borç yaratan kaynaklarla karşılanması cari açığın sürdürülemeyen bir boyuta taşınabilmesi ihtimalini ortaya çıkarmaktadır. Bu bakımdan iç dengenin sağlanması noktasında kamu harcamalarının azaltılması ve bütçe dengesinin sağlanarak mali disiplinin oluşturulması sürdürülebilirlik üzerinde olumlu etki ortaya çıkaracaktır.

Türkiye'nin dış ekonomik açığı enerji giderlerinin fazlalığı yanında, yüksek teknoloji ürünlerindeki düşük ihracat-yüksek ithalat düzeyinden de kaynaklanmaktadır. Türkiye'nin dış açık problemini çözmesi için göreli olan bu dezavantajlarından kurtulması gerekir. Ticarete konu olan mallar arasında teknolojik değeri yüksek ürünlerin ihraç edilmesi hem büyük oranda ülkeye döviz girişi sağlayacak hem de cari açığın kapanmasına yardımcı olacaktır.

Türkiye'nin genç ve dinamik nüfusu büyük bir potansiyel barındırmaktadır. Eğitilmiş insan gücünün artması uzun vadede Türkiye ekonomisinde kararlı dengenin oluşmasında etkili olacaktır. Ülkelerin sahip olduğu inovasyon ve bilgi düzeyi küresel rekabet gücünü belirlemektedir. Türkiye'nin içinde bulunduğu dönemi Ar-Ge ve iş gücü yetkinliklerinin geliştirilmesine dönük harcaması, uzun dönemde uzak doğudaki ve diğer başka pazarlardaki rakiplerine karşı rekabette üstünlük sağlayacaktır. $\mathrm{Bu}$ bağlamda, eğitime yatırım yapmak hem bilişim teknolojilerinin gelişimi sağlayacak hem de verimliliği artırarak sürdürülebilir büyümeyi mümkün kılacaktır. Dış ticarette rekabetçiliğin ön planda tutularak verimliliğin ve dolayısıyla da üretimin artması makroekonomik kırılganlıkları azaltacaktır. İnovasyon yapmadan ekonomik büyüme ve kalkınma gerçekleşmeyeceğinden dış ekonomik denge kapanmayacaktır. Özellikle son yıllarda gittikçe daha önemli hale gelen; bilişim, finans, yapay zekâ, uzay, yenilenebilir enerji, e-ticaret, taşımacılık-lojistik, çevre, ilaç, tarım ve gıda gibi alanlarda yapılacak yatırımlar Türkiye'nin, katma değeri yüksek olan, bilgiye ve inovasyona dayalı üretim 
yapısını güçlendirecektir. Söz konusu alanlarda yaşanacak ilerlemeler Türkiye'nin dış bağımlılıktan kurtulmasına yardımcı olacak ve gelişmiş ülkeler sınıfına bir adım daha yaklaştıracaktır.

\section{KAYNAKÇA}

Akınc1, M., Akıncı, G. Y \& Yılmaz, Ö. (2016). Dördüz Açıklar: Ütopya Mı Yoksa Gerçek Mi?, Paradoks Ekonomi Sosyoloji ve Politika Dergisi, Cilt; 12, Say1; 1, s; 22-47

Altunöz, U. (2018) Cari Açık, Bütçe Açığı ve Yatırım-Tasarruf Açığı Bağlamında Türkiye'nin Üçüz Açık Analizi, Maliye Dergisi, Sayı; 175, s; 115-139

Alp, B. (2013) Türkiye'deki Reel Sektör Firmalarında Borç Dolarizasyonu ve Reel Kur Değişimlerinin Bilanço Etkisi. TCMB Uzmanlık Yeterlilik Tezi.

Asheim, G. B. (1994) Sustainability: Ethical Foundations and Economic Properties, The World Bank, Say1; 1302, s. 1-32

Aydın, M. K. \& Beşballı, S. G. (2018) Türkiye'nin Cari Açık Sorunu Üzerine Bir Değerlendirme, Bilgi, Cilt; 20, Say1; 1, s. 1-14

Bahçekapıl1, C. (2015) Türkiye Ekonomisinde 2011 Sonrası Sınırlı Büyümenin Nedenleri Üzerine Bir Analiz. Marmara Üniversitesi İktisadi ve İdari Bilimler Dergisi, Cilt; 37, Sayı; 1, s. 111-124

Başçı, E. (2013) Türkiye'nin Büyüme Potansiyeli Sunumu, CEO Club Toplantısı, TCMB, s. 1-21

Beyaz, Z., \& Karabacak, G. (2018) Türkiye'de Turizm Gelirlerinin Cari İşlemler Dengesi Üzerindeki Etkisi. EUropean Journal of Managerial Research (EUJMR), Cilt; 2, Sayı; 2, s. 56-75

Carranza, L. (2002) Current Account Sustainability, Khan, Mohsin. S., Nsouli, Saleh. M., ve Wong, Chorng-Huey (ed), Macroeconomic Management: Programs and Policies, International Monetary Fund, s. 99-138

Chinn, M. D. (2005) Getting Serious About The Twin Deficits. Washington DC: Council on Foreign Relations.

Doğan, S. \& Tunalı, Ç. B. (2012) Türkiye'de Bütçe Açığı-Cari İşlemler Açığı İlişkisi (2001 Krizi Sonrası Döneme İlişkin Bir Değerlendirme), Maliye Araştırma Merkezi Konferansları, Sayı; 58, s. $1-26$

Dornbusch, R., Fischer, S. \& Startz, R. (2011) Macroeconomics, McGraw-Hill, Inc, New York

Eğilmez, M. (2009) Makro Ekonomi Türkiye'den Örneklerle. Remzi Kitapevi.

Eraydın, K. (2015) Petrol Fiyatlarındaki Düşüşün Nedenleri ve Etkileri, Türkiye İş Bankası İktisadi Araştırmalar Bölümü, İstanbul 
Erbaykal, E. (2007) Türkiye'de Ekonomik Büyüme ve Döviz Kuru Cari Açık Üzerinde Etkili Midir? Bir Nedensellik Analizi, Uluslararası Yönetim İktisat ve İşletme Dergisi, Cilt; 3, Sayı; 6, s. 81 88

Eşiyok, B. A. (2012) Türkiye Ekonomisinde Cari Açık Sorunu ve Nedenleri, Finans Politik \& Ekonomik Yorumlar, Cilt; 49 Sayı; 569, s. 63-85

Geçer, T. (2018) Eximbank "Teminat Mektubu" Toplama Bankası Mı?, Uluslararası Ticaret ve Ekonomi Araştırmaları Dergisi, Cilt; 1, Sayı; 2, s. 81-86

Genç, S. Y., Yardımcı, M. E., \& Göçeri, K. (2017) Türkiye Ekonomisinde Cari Açık Sorununun Yapısal Nedenleri ve Sürdürülebilirliği (2002-2016), Dünden Bugüne Ekonomi Yazıları, Kocaeli Üniversitesi Vakfı Yayınları, Say1; 82

Irena (2020) Renewable Energy Statistics 2020, The International Renewable Energy Agency, Abu Dhabi

Kalkınma Bakanlığg (2014) Türkiye'de Cari İşlemler Açığı, Özel İhtisas Raporu Komisyonu, Ankara

Karagöl, V., \& Erdoğan, M. (2017) Türkiye Ekonomisinde Cari Açığın Belirleyicileri ve Cari Açığa Yönelik Politika Uygulamaları, Ulakbilge Sosyal Bilimler Dergisi, Cilt; 5; Sayı 10, s. 353-381

Milesi- Ferretti, G. M. \& Razin, A. (1996) Persistent Current Account Deficits: A Warning Signal?, International Journal of Finance \& Economics, Cilt; 1, Say1; 3, s. 161-181

Öztürk, E. N. (2017) Cari Açık Problemi Çerçevesinde Türkiye'de Ara Mal ve Enerji İthalatı, Uluslararası Ekonomik Araştırmalar Dergisi, Cilt; 3, Say1; 4, s. 559-568

Saçık, S. Y. \& Alagöz, M. (2010) Türkiye'de Cari İşlemler Açı̆̆ı Sorunu ve Borçlanma ile İlişkisi, Ekonomi Bilimleri Dergisi, Cilt; 2, Say1; 2, s. 113-120

Sezgin, Z., Sevim, C. \& Kalyoncu, F. (2015) Türkiye Ekonomisinde Cari Açı Sorunu: Tasarrufların Önemi ve Bireysel Emeklilik Sistemi, Kırıkkale Üniversitesi Sosyal Bilimler Dergisi, Cilt; 5, Say1; 2 , s. 227-240

Subaşat, T. (2010) Cari Açık Nedir? Doğurduğu Riskler Nelerdir?, Turan Subaşat ve Hakan Yetkiner (ed), Küresel Kriz Çerçevesinde Türkiye'nin Cari Açık Sorunsalı, Efil Yayınları, s. 1-21

TCMB, (2015) Tasarruf-Yatırım Dinamikleri ve Cari İşlemler Dengesi Gelişmeleri.

TÜIK, (2019) Y1llık Sanayi Ürün (PRODCOM) İstatistikleri, 2019

Telatar, O. M. \& Terzi, H. (2009) Türkiye'de Ekonomik Büyüme ve Cari İşlemler Dengesi İlişkisi, Atatürk Üniversitesi İktisadi ve İdari Bilimler Dergisi, Cilt; 23, Sayı; 2, s. 119-134

Uygur, E. (2012) Türkiye'de Cari Açık Tartışması, TEK Tartışma Metni, Sayı; 25, s. 1-32 
Wray, L. R. (2006) Twin Deficits and Sustainability, Levy Economics Institute, Say1; 06-3, s. 1-6

Yanar, R. ve Kerimoğlu, G. (2011) Türkiye'de Enerji Tüketimi, Ekonomik Büyüme ve Cari Açık İlişkisi”, Ekonomi Bilimleri Dergisi, Cilt; 3, Sayı; 2, s. 191-201

https://www.hmb.gov.tr/kamu-finansmani-istatistikleri

https://ms.hmb.gov.tr/uploads/2020/04/Ekonomi_Sunumu-4.pdf

https://muhasebat.hmb.gov.tr/merkezi-yonetim-butce-istatistikleri

https://www.sbb.gov.tr/kamu-kesimi-genel-dengesi/

https://yigm.ktb.gov.tr/TR-201116/turizm-gelirleri-ve-giderleri.html 